NCAEE 2017

National Conference on Advances in Electrical Engineering

NMAM Institute of Technology, Nitte

Vol. 5, Special Issue 2, April 2017

\title{
Feedback Control of an Interleaved Buck Converter with Improved Conversion Ratio
}

\author{
Sridevi D ${ }^{1}$, Ravikiran Rao ${ }^{2}$ \\ PG Scholar, Electrical and Electronics Engg., NMAM Institute of Technology, Nitte, India ${ }^{1}$ \\ Assistant Professor, Electrical and Electronics Engg., NMAM Institute of Technology, Nitte, India ${ }^{2}$
}

\begin{abstract}
Proposed Interleaved Buck Converter (IBC) which has a continuous input current, high step down conversion ratio, extremely low output current ripple. The proposed converter can provide current sharing control method. These benefits can be obtained without any additional stress on the circuit components. Proposed converter is suitable for high power application and operating duty cycle is below 50\%.The feedback loop is used for the proposed buck converter to produce constant output voltage. The feedback loop control is given using PI control. Simulation is carried out with MATLAB and results are obtained.
\end{abstract}

Keywords: Interleaved Buck Converter, Improved Conversion Ratio, Feedback Control.

\section{INTRODUCTION}

An interleaved buck converter is extensively used as a stepdown, low output current ripple, non-isolated, and high output current with simple structure and low complexity. Conventional IBC has some advantages like power distribution, fast transient response,passive component size reduction and current ripple cancellation. When high input voltage is applied to the conventional IBC, voltage stress of all switches is equal to the input voltage.High voltage elements suffer from high forward voltage drop, high output capacitor, high on resistance[1].At high switching frequency the IBC operates with extremely small duty cycle(D), which causes very short regulation period and high step down. At small duty cycle input current ripple,switching peak current and filter size increases[2].In an IBC, little mismatch in the duty cycles of two interleaved modules with conversion ratio is equal to $\mathrm{D}$, the module with higher $\mathrm{D}$ operates in continuous inductor current mode and other module operates in descrete inductor current mode(DICM) mode to equalise the gain of two modules.As a result, current sharing becomes unbalanced between two interleaved modules. Therefore the current sharing is very sensitive to the mismatch in dutycycles[3].The lifetime of the Fuel cell and Lead acid battery depends on the ripple of the current drawn from them which has to be low.The main limitation of the standard converters is that it requires high inductor value in order to accomplish low output current ripple to minimize the inductor losses[4].In order to reduce the current ripple paralleled converters with interleaved control is an attractive technique. Conventional IBC has pulsed input current in CICM.

The proposed converter does not need any additional current-sharing control module. The proposed converter almost suppresses the effects of mismatches in the duty cycles of the modules.

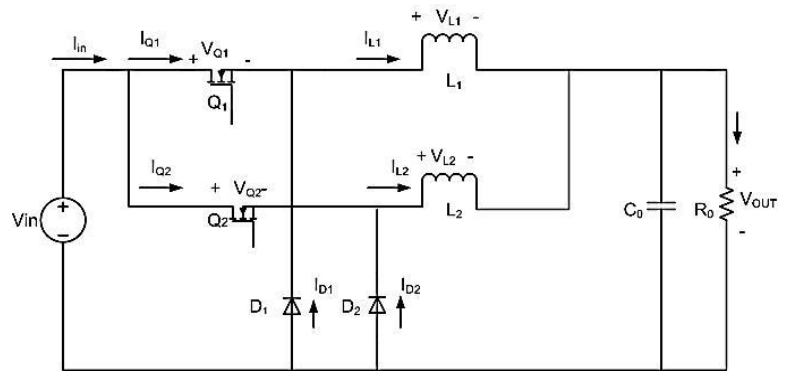

Fig.1 Conventional IBC

\section{OPERATION PRINCIPLE OF PROPOSED IBC}

Fig 2. shows the proposed converter in which two capacitors are connected at the input and an auxillary inductor at the output.The two active switches are controlled by two PWM pulses which are $180^{\circ}$ out of phase.

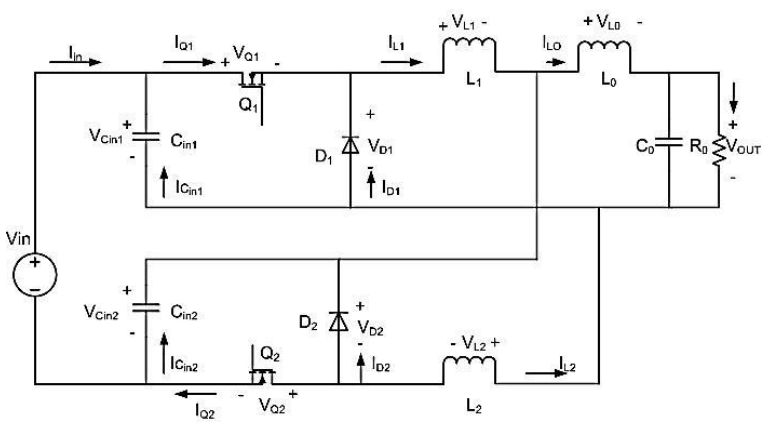

Fig. 2 Proposed IBC 
The following assumptions are made during the analysis.

1) All active switches and diodes are ideal.

2) Capacitors $C_{i n 1}, C_{i n 2}$, and $C_{o}$ are large enough so that their voltage variations can be ignored. Also, $\mathrm{C}_{\mathrm{in} 1}=\mathrm{C}_{\mathrm{in} 2}$.

3) The currents in $L_{1}$ and $L_{2}$ are constant, and also, $L_{1}=L_{2}$

Modes of operation:

Mode 1:

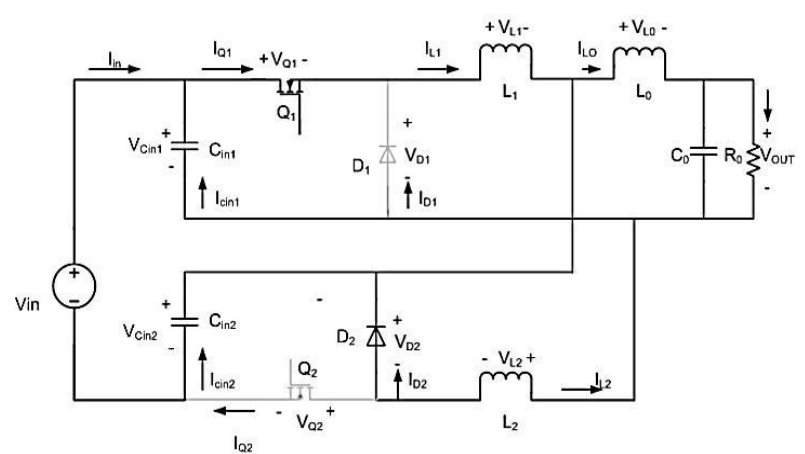

Fig. 3 Mode $1\left[\mathrm{t}_{0}-\mathrm{t}_{1}\right]$

Interval 1 [to- $\left.\mathrm{t}_{1}\right]$ :

Prior to this interval, both the switches are off, the freewheeling diodes are conducting and the input capacitors $\mathrm{C}_{\mathrm{in} 1}$ and $\mathrm{C}_{\mathrm{in} 2}$ are charged. At $\mathrm{t}_{0}, \mathrm{Q}_{1}$ is turned on, so $\mathrm{D}_{1}$ turns off.In this interval, $\mathrm{C}_{\mathrm{in} 2}$ is charged through $\mathrm{V}_{\text {in }}$ and $\mathrm{L}_{1}$ and $\mathrm{C}_{\mathrm{in} 1}$ is being discharged through $\mathrm{L}_{1}-\mathrm{L}_{0}-\mathrm{C}_{0}$. In addition, $\mathrm{L}_{1}$ current is increasing through both of the mentioned current paths. $\mathrm{L}_{2}$ current is decreasingin this state.

Mode 2:Operation of Mode $2\left[\mathrm{t}_{1}-\mathrm{t}_{2}\right]$ and Mode $4\left[\mathrm{t}_{3}-\mathrm{t}_{4}\right]$

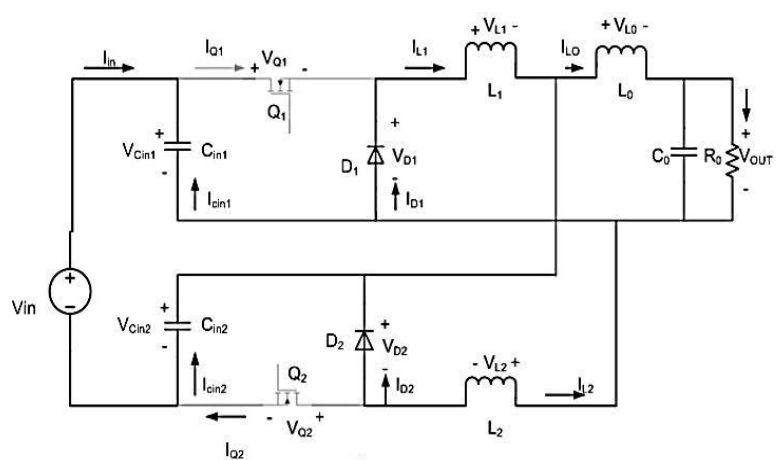

Fig. 4Mode $2\left[\mathrm{t}_{1}-\mathrm{t}_{2}\right]$ and Mode $4\left[\mathrm{t}_{3}-\mathrm{t}_{4}\right]$

Interval $2\left[\mathrm{t}_{1}-\mathrm{t}_{2}\right]$ : This interval starts when $\mathrm{Q}_{1}$ turns off. By turning $\mathrm{Q}_{1}$ on, $\mathrm{L}_{1}$ continues its current and turns $\mathrm{D}_{1}$ on. Part of the inductor current which was owing in $\mathrm{C}_{\mathrm{in1}}-\mathrm{L}_{1}$ $\mathrm{L}_{\mathrm{o}}-\mathrm{C}_{\mathrm{o}}$ continues its path through $\mathrm{D}_{1}-\mathrm{L}_{1}-\mathrm{L}_{\mathrm{o}}-\mathrm{C}_{\mathrm{o}}$, and the other part of $\mathrm{L}_{1}$ current runs through $\mathrm{V}_{\text {in }}-\mathrm{C}_{\mathrm{in} 1}-\mathrm{D}_{1}-\mathrm{L}_{1}-\mathrm{C}_{\mathrm{in} 2}$. Therefore, during this interval, $\mathrm{L}_{1}$ and $\mathrm{L}_{2}$ aredischarging and $\mathrm{C}_{\mathrm{in} 1}$ and $\mathrm{C}_{\mathrm{in} 2}$ are charging through $\mathrm{V}_{\mathrm{in}}-\mathrm{C}_{\mathrm{in} 1}-\mathrm{D}_{1}-\mathrm{L}_{-} \mathrm{C}_{\mathrm{in} 2}$ and $\mathrm{V}_{\mathrm{in}}-\mathrm{C}_{\mathrm{in} 1}-\mathrm{L}_{2}-\mathrm{D}_{2}-\mathrm{C}_{\mathrm{in} 2}$.

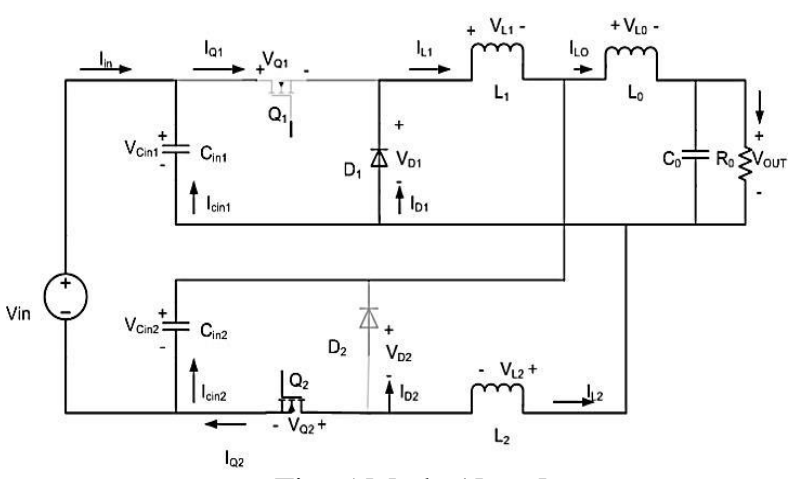

Fig. 5 Mode $1\left[t_{0}-t_{1}\right]$

Due to symmetric operation of two modules in an interleaved converter, the operations of interval 3 and interval 4 are similar to those of interval 1 and interval2.

\section{SIMULATION AND RESULTS}

A. Open Loop Control of Proposed IBC

Proposed IBC has extremely low output current ripple and high step down conversion ratio in comparison with the conventional IBC, thusthe duty cycles of switch can be extended with reduced peak current. The output current ripple of the converter is considerably low even though a very small inductor is used.

TABLE1 Parameter values of the proposed IBC

\begin{tabular}{|c|c|}
\hline Input Voltage & $200 \mathrm{~V}$ \\
\hline Output Voltage & $24 \mathrm{~V}$ \\
\hline Power Level & $240 \mathrm{~W}$ \\
\hline Switching frequency & $100 \mathrm{KHz}$ \\
\hline Inductors $\mathrm{L}_{1}$ and $\mathrm{L}_{2}$ & $100 \mathrm{uH}$ \\
\hline $\mathrm{L}_{0}$ & $5 \mathrm{uH}$ \\
\hline Input Capacitors $\mathrm{C}_{1}$ and $\mathrm{C}_{2}$ & $4.4 \mathrm{uF}$ \\
\hline Output Capacitor $\mathrm{C}_{0}$ & $1 \mathrm{uF}$ \\
\hline
\end{tabular}

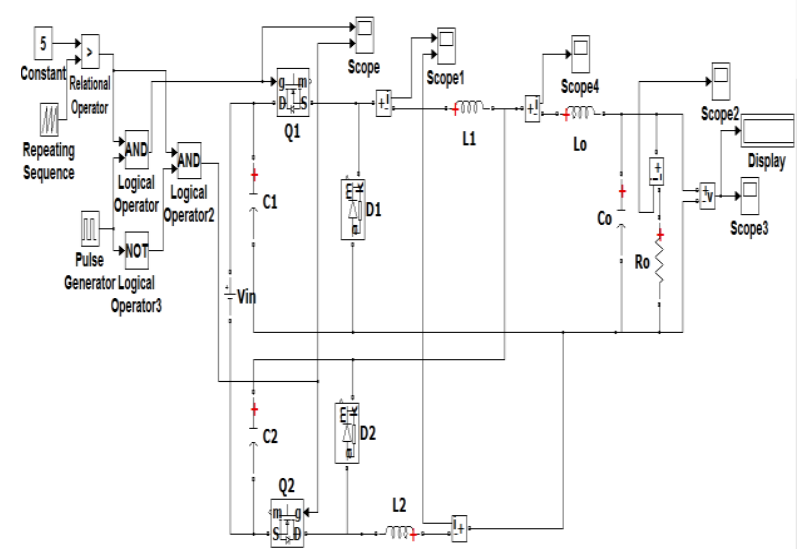

Fig. 6 Open loop control of proposed IBC Mode3: 
$B$. Output voltage and output current of the proposed converter:

Output voltage of the proposed converter is $27.85 \mathrm{~V}$ but with a minimum ripple of $0.2 \mathrm{~V}$.Output current ripple is decreased to $0.07 \mathrm{~A}$ for a duty ratio of 0.45 .

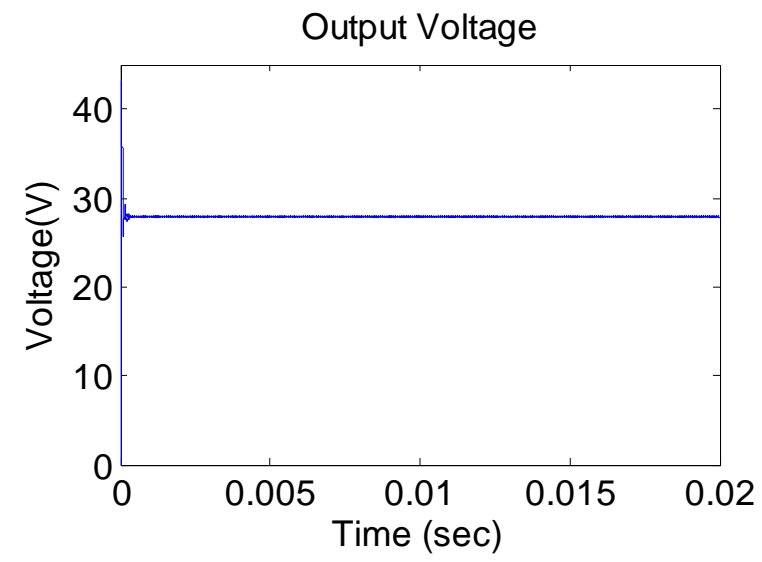

Fig. 7 Output Voltage

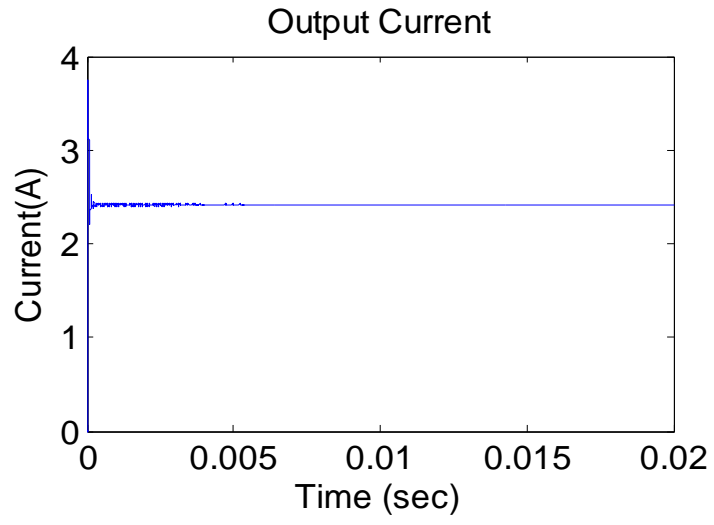

Fig. 8 Current through the Load

C) Closed Loop Control of Proposed IBC:

To produce constant output voltage, feedback loop is used. In feedback system output voltage is compared with a reference voltage and a PWM wave is generated.

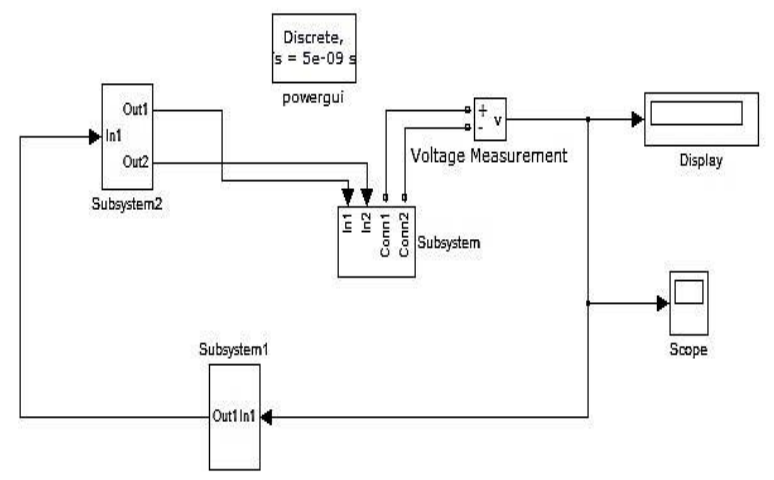

Fig. 9 Closed loop control of proposed IBC
$C$. Output voltage and output current of the proposed converter:

Output voltage of the closed loop IBC is $23.92 \mathrm{~V}$ which is observed to be constant with any changes in the supply voltage.

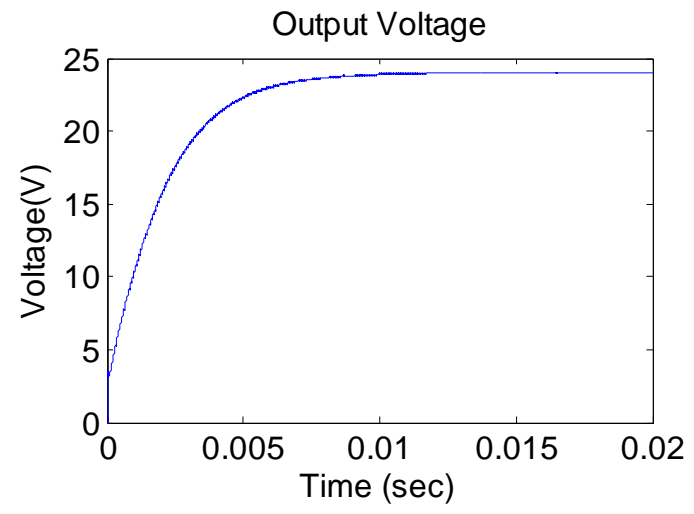

Fig. 10 Output Voltage

In comparison to other IBCs, the output current ripple is very low. Output current of the proposed closed IBC is $10 \mathrm{~A}$ with minimum ripple of $0.07 \mathrm{~A}$ for a duty ratio of 0.45 .

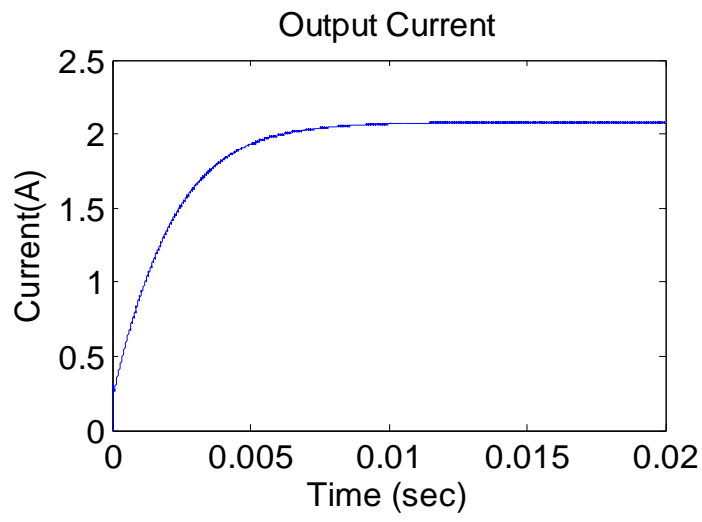

Fig. 11 Current through the Load

Current through the inductor and ripple is observed to be $0.263 \mathrm{~A}$ for duty ratio of $0.45 \mathrm{~A}$.

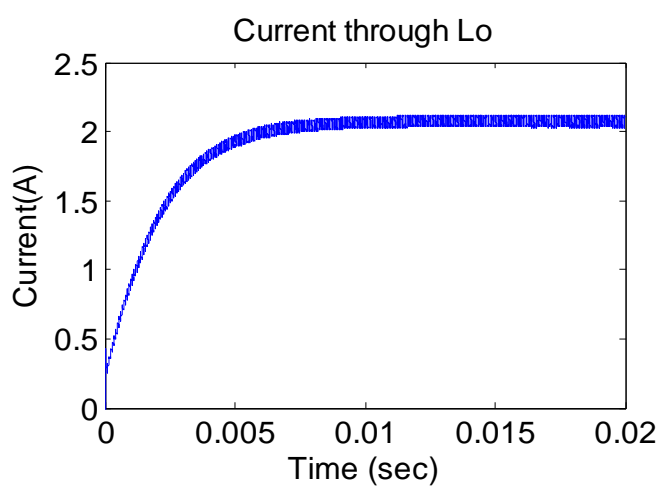

Fig. 12 Current through the inductor $\mathrm{L}_{\mathrm{o}}$ 
In the proposed converter input current is continuous and Also, all of these benefits are obtained without any does not need any additional current-sharing control additional stress on the components. The closed loop module. As aresult,current sharing between two control of the paper is carried out using MATLAB and interleaved modules becomes balanced.

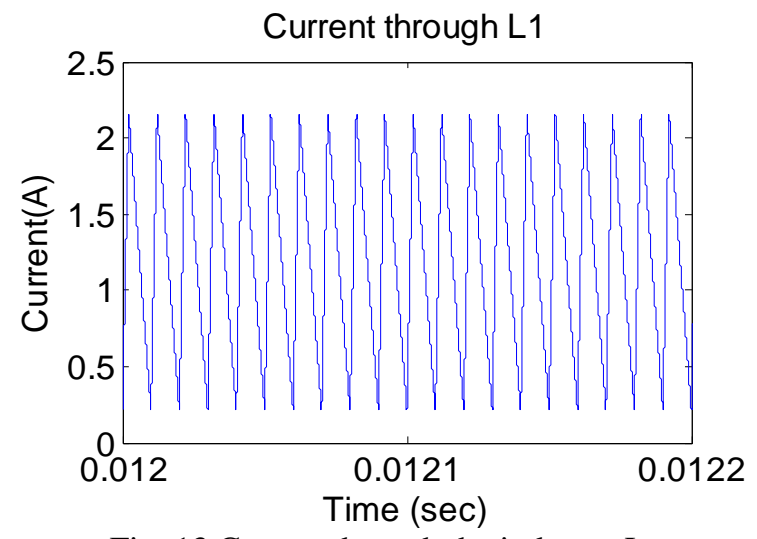

Fig. 13 Current through the inductor $\mathrm{L}_{1}$

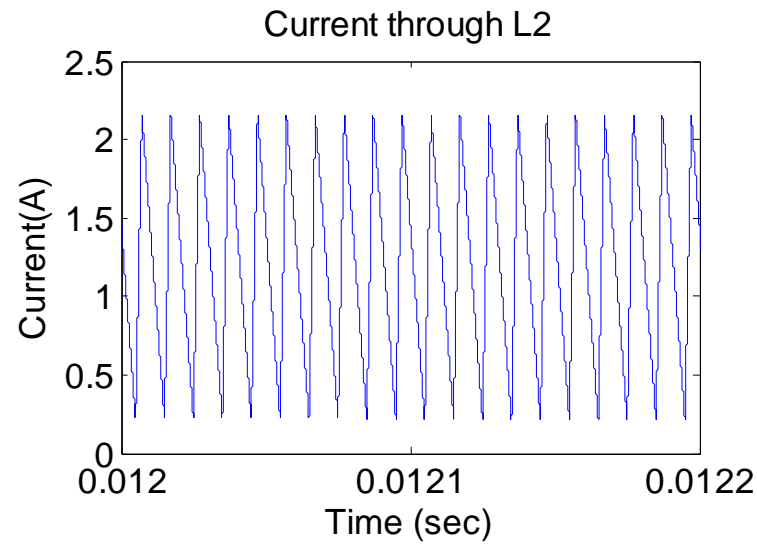

Fig. 14 Current through the inductor $\mathrm{L}_{2}$

D. Comparison of results of all the parameters

TABLE.2. Comparison of results

\begin{tabular}{|c|c|c|}
\hline Parameters & $\begin{array}{c}\text { Conventional } \\
\text { IBC }\end{array}$ & $\begin{array}{c}\text { Proposed } \\
\text { IBC }\end{array}$ \\
\hline Output Voltage & $42.8 \mathrm{~V}$ & $23.25 \mathrm{~V}$ \\
\hline Output Voltage Ripple & $0.9 \mathrm{~V}$ & $0.2 \mathrm{~V}$ \\
\hline Output Current Ripple & $0.36 \mathrm{~A}$ & $0.07 \mathrm{~A}$ \\
\hline
\end{tabular}

\section{CONCLUSION}

The proposed converter provides current sharing between two interleaved modules without using an additional current-sharing control module.The proposed converter has the advantages of continuous input current, extremely low output current ripple, low switching losses, and improved step-down conversion ratio, which makes it a proper candidate for high power, low output current ripple, high input voltage, and non-isolated step-down converters. results are obtained. The closed loop control is done using a PI controller.

\section{ACKNOWLEDGMENT}

I express my sincere gratitude to Mr. Ravikiran Rao, Assistant Professor, Dept. of E\&E, for his cooperation and guidance.I extend my sincere thanks to our esteemed institution NMAM Institute of Technology, Nitte for supporting me in all the ways possible.

\section{REFERENCES}

[1] X. Du, L. Zhou, and H.-M. Tai, "Double-frequency buck converter," IEEE Trans. Ind. Electron., vol. 56, no. 5, pp. 16901698, May 2009.

[2] D.Wang, X. He, and J. Shi, "Design and analysis of an interleaved flyback forward boost converter with the current autobalance characteristic,'IEEE Trans. Power Electron., vol. 25, no. 2, pp. 489-498, Feb. 2010.

[3] P.-W. Lee, Y.-S. Lee, D. K.-W.Cheng, and X.-C. Liu, "Steady-state analysis of an interleaved boost converter with coupled inductors," IEEE Trans.Ind.Electron., vol. 47, no. 4, pp. 787-795, Aug. 2000.

[4] J. Garcia, A. J. Calleja, E. López rominas, D. Gacio Vaquero, and L. Campa, "Interleaved buck converter for fast PWM dimming of high brightness LEDs," IEEE Trans. Power Electron., vol. 26, no. 9, pp. 2627-2636, Sep. 2011.

[5] MortezaEsteki, BehzadPoorali, EhsanAdib, and HoseinFarzanehfard, Interleaved Buck Converter With Continuous Input Current, ExtremelyLow Output Current Ripple, Low Switching Losses, and Improved Step-Down Conversion Ratio,"IEEE Transactions On Indusrial Electronics, VOL. 62, NO.8, August 2015

[6] NavamiMohan and Dr.N.Prabhakaran, IClosed Loop Control of an Interleaved Buck Converter with High Step-Down Conversion Ratio and Low Switch Voltage Stress,"International Journal Of Innovative Research In Elecrtical,Electronics,Instrumentation And ControlEngineerig Vol. 3, Issue 9, September 2015

[7] Nithya K and PriyaG.Das, Interleaved Buck Converter with Closed Loop Control and Higher Step-Down Conversion Ratio,"Transactions on Engineering and Sciences,Vol.3, Issue 4, April-June 2015 